\title{
Media Narrative Creation of Inter-Religious Conflict and Its Repercussion on National Development in Nigeria: A Dialectic Discourse on the Media's Role as an Instrument for Conflict Construction and Management
}

\author{
Adamkolo Mohammed Ibrahim* \\ Research Scholar and Lecturer, Department of Mass Communication, University of Maiduguri, PMB 1069, \\ Borno State, Nigeria; PhD Research Candidate, Bayero University, Kano, PMB 3011, Kano State, Nigeria \\ Muhammad Nura Nguru \\ Instructor, Department of Mass Communication; Information Officer, Information Unit, Office of the Rector, the \\ Federal Polytechnic, PMB1006 Damaturu, Yobe State, Nigeria
}

\begin{abstract}
This paper examined the extent to which the mass media narrative serves as an instrument of the escalation, degeneration and de-escalation of religious-related conflicts in Nigeria, especially in the Northern part of the country and the consequent effects of the role of the mass media in national development. Thus, the media narrative is seen as a factor constructing religious conflicts which occur so often. The sources of the literature reviewed were the main method employed in the collection of data. Grounded in the mediatisation theory perspective, this paper examined news reports and analysis, editorials, contents of newspapers, radio broadcasts, television news and international news agencies' reports on ethnoreligious conflicts. From the analysis, the paper highlights that even in instances when conflicts arose as a result of other factors, they usually assumed religious colourations thus making them intractable and the mass media in the country during reportage of inter-religious conflicts play roles as diverse as the interests of their owners and editors: geographical locations and ethnic and religious affiliations. This paper, therefore, recommends a paradigm shift in the inter-religious narrative by the media to play down conflict situations rather than escalate them for national development. This is because conflicts, generally, are complex and so their narrative should be handled with care to avoid generation and escalation of further conflicts. This paper also proposes that ethnic identity, political identity and religious identity influence media narrative of religious conflicts in Nigeria. Policy recommendations were offered at the end.

Keywords: Islam and Christianity in Nigeria, Media and ethnoreligious conflict in Nigeria, Media and interreligious conflict in Nigeria, Media and conflict resolution, Media narrative of conflicts, Mediatisation of religious issues
\end{abstract}

DOI: $10.7176 / \mathrm{NMMC} / 91-04$

Publication date:June 30th 2020

\section{Introduction}

Since independence in 1960, Nigeria has suffered some of the most obstinate conflicts, most of them constructed from differences in religious and ethnic identities. Religious and ethnic nationalism has led to conflicts about control of state power, unequal allocation of resources, citizenship issues, state collapse, economic decline and religious clashes. The country has been pushed hither and thither by recurrent crises of regional or state illegitimacy, often impairing efforts at economic transformation, democratisation, national cohesion and stability. The media of mass communication, and in recent years, social media aided by the technological prowess of the internet are at the centre of these politico-religious crises as arbiters and sometimes, as instigators. Ideally, religion should not be a platform for conflict and crises. Unfortunately, the management of religion and the organisation of different bodies of believers and worshippers have given rise to conflicts in Nigeria. Muslims and Christians have clashed over situational supremacy, access to prestige, power and privilege as well as information management, especially concerning the political atmosphere in the country (Odiase-Alegimenlen, 2001; Salawu, 2009; Sule, 2015).

To explain the influence of mass media on the readers and audiences, Marshall McLuhan (who is often called the media prophet), in his book "Understanding Media: The Extensions of Man" (1964) cited in Salawu (2009) coined a phrase "the medium is the message". The modern era is the age of the media. It is an age of communication technology and information revolution. At this stage of development, the mass media are more pervasive than ever before. The media have virtually revolutionised the world into a global village of communication and interaction. The traditional role of mass media as defined by scholars is to inform, educate, entertain and persuade the people. The media can bring change in the behaviour and attitude of the people by emphasising certain issues. Meanwhile, with the revolutionary progress of mass communication, an unprecedented opportunity has been created to share 
and exchange information for knowledge and social change. But, the media have turned the affairs into a war of words. Today's wars in the battlefields are the cumulative actions of what was designed, discussed, and persuaded through the media in moulding a favourable public opinion (Said, 1997).

The power of media has been formidable or centuries; especially the power of live-action video images on television and most recently, the power of the internet has become even more formidable. Books, newspapers, magazines, video cartoons, movie, radio, television and internet-based sites are now widely used to manipulate the information, facts and beliefs. The instrument of mass communication in the modern world has an enormous potential for inducing newer images in shaping global politics, culture and the public believes. Mass media are both a force for integration and dispersion and individuation in society. With the emergence of modern communication technology, society as a whole is now a simple hostage at the hands of the media. The time has come to ask whether the people (audiences) are being managed, manipulated, massaged or brainwashed by the media. Media practitioners with a biased mind often become propagandists of their personal opinion, using the media as their vehicle. The media are also controlled by their sponsors (McQuail, 1979).

Moreover, the fact that an average Nigerian is very religious was observed by some sources (Oluduro, 2010, p. 209; Ekundayo, 2013, p. 29). Religion plays a critical role in Nigerian society and has expressed itself as a potent force in the geopolitical development of the country. This force which has been used to unite Nigerians is the same force that has led to numerous conflicts in the country. Nigeria has been engulfed in numerous religious crises and/or conflicts between 1980 and 19941 (Odukoya \& Çanc1, 2016; Warner, 2012, p. 38).

Due to their tendency to spread into other areas after an early stage in one area, religious conflicts have gained notoriety as the most violent crimes in Nigeria. Most of these conflicts occur in the middle-belt and along with the culturally borderline states of the predominantly Muslim North, and also take place between Hausa-Fulani groups and non-Muslim ethnic groups in the South (Osaghae \& Suberu, 2005, p. 19). In conflicts ${ }^{1}$ of this nature occurring along with the convergence of ethnic and religious lines, it is often very difficult to tell the differences between religious and ethnic crises because the dividing line between them is slimmer than thin.

\section{Background}

Generally, any discussion on religion in Nigeria must disregard the reference to the history of Muslim and Christian relations. Equally influential in this context is politics. However, the Nigerian political scene is not dominated by religion but has been greatly influenced by it (Atanda, 1989; Ilesanmi, 1997). Nigeria, like many other colonised African nations, have sought to negotiate its extensive ethnic and religious pluralism equitably, and channel such as national integration. The much-talked-about imbalance in the country was as a result of the advantages gained by those who received western education (Ekoko, 1989). It was in the South of the country that Christian missionaries were most active in establishing schools. Due to the British policy of non-intervention toward the Muslims in the North, the latter did not gain the benefits of western education. This resulted in a lasting and destabilising dichotomy and is firmly imprinted on the historical memory of Muslims (Iruonagbe, 2009; Sule, 2015).

Nigeria is synonymous with deep divisions which cause major political issues to be vigorously and violently contested along the lines of intricate ethnic, religious and regional divisions. Issues that raise the most dust are those regarded essential for the existence and the validity of the state. Opposing and contending assemblages tend to assume an exclusionary winner-take-all approach. These issues include the control of state power, allocation of resources and citizenship. As a result, states with such divisions are disposed to be delicate and unstable because almost by definition, they have very little in common concerning convergence and harmony which are necessary to reduce the centrifugal forces that rip them apart (Osaghae \& Suberu 2005, p. 4).

Therefore, breakdown, breakaway, civil strife, civil war, minority nervousness, and violent clashes, all of which would typically be regarded unusual in normal states are common forces or actual occurrences in divided states (Osaghae \& Suberu 2005, p. 4). Because of a complicated network of politically silent identities, coupled with a history of protracted and seemingly stubborn wars and instability, Nigeria is high on the list as one of the most unstable states in Africa. Since its independence, Nigeria has been driven hither and thither by recurrent crises of regional or state illegitimacy, often impairing efforts at democratisation, stability, economic transformation and national cohesion. A peak of the crisis appears to have occurred during the civil war of the 1960s, which began shortly after independence (Iruonagbe, 2009; Okpanachi, 2010; Toure, 2012). Since 1999 when Nigeria transited to a civilian rule, the country has witnessed a rapid increase in the number of conflicts.

A high level of corruption and the looting of state resources is another serious and 'epidemic' (Dike, 2005) problem that makes all forms of conflict and trouble worse in Nigeria. The country is "richly endowed with natural resources and high-quality human capital" (Ogbeidi, 2012, p. 1), but corruption is one of the main reasons that affect the development of the country negatively. The appropriation of state resources by certain hands makes poverty and bitter anger inevitable aspects of the daily socio-economic and political routine. In this sense, though corruption is not peculiar to Nigeria, many sources call it the "bane of the country" (Dike, 2005; Ogbeidi, 2012, p. 21). And of course, corruption is considered to be one of the main causes of religious conflicts (Nwankwo, 
2015). Poverty and injustice caused by corruption weaken any sense of mutual tolerance, social solidarity or coexistence, while reawakening social hatred, radicalism and violence. For this reason, corruption is seen as one of the most important issues that have to be resolved to cope with religious conflicts in Nigeria (Odukoya \& Çanc1, 2016; (Sule, 2015).

Issues of protracted incidences of violent inter-religious conflicts have a very wide area of research in Nigeria and even in Africa South of the Sahara and other developing nations. While much research conducted on their causes or origins and the way forward, limited attention is given to the study of the impacts of media reportage of inter-religious conflicts and their implications for socio-economic development. This paper aimed to assess the impacts of the news media reportage of inter-religious conflicts and their implications on socio-economic development in Nigeria. It looks at the notion of media reportage of religious conflicts in an attempt to explain religious conflicts and the complexities of social change in a modern Nigeria based on the theoretical perspective of the Mediatisation Theory.

\subsection{Theoretical Framework}

This paper focuses on the links between religion, the mass media and national development in Nigeria. The aim is to understand the degree to which religion affects the mass media in society and how the media narrative of interreligious conflict, in turn, affects conflict escalation or de-escalation. Hence, this paper adopted the theory of mediatisation perspective, which dwells on the role and influence of the mass media on other social institutions such as politics, family and religion. As Sule (2015) noted, three great scholars can be identified with their various positions on religion and society. These scholars propounded different theories in their efforts to address problems associated with the interaction of religion and society. "Fredrick Hegel, Karl Marx and Max Weber all offer a wide array of thoughts and ideas regarding how religion influences the society and vice versa" (p. 15).

The theory of mediatisation, propounded by Stig Hjarvad (2011) seeks to explain the interplay between religion and the mass media. It asserts that the mass media are an important source of information about religious issues and that religious information and experiences are influenced "according to the demands of popular media genres" (p. 119). This theory postulates that the mass media have taken over many of the cultural and social functions of institutionalised religions and provide spiritual guidance, moral orientation, ritual passages and a sense of community and belonging (Abdel-Adil, 2017; Sule, 2015). Therefore, the literature review presented in this paper is guided by the mediatisation theory to discuss on how the nature of media narrative of religious issues can be central to the escalation or de-escalation of inter-religious conflicts in Nigeria.

\section{Media Narrative Creation of Inter-Religious Conflicts}

The media are naturally attracted to conflict because conflict is intrinsically linked to journalism so much so that some definitions of news often begin with the term "conflict." Since abnormality makes news and violent conflict is an abnormality, the mass media tend to thrive on conflict as conflict attracts readers, viewers and listeners to the media. The prime news value of the media are sometimes conflict, disorder and negative events as good news stories receive less media attention than bad news (Sule, 2015).

The mass media constitute a space in which the conflicts of a society can be articulated and are more or fewer actors in conflicts. Also, the combatants in conflict usually relate to each other either on the battlefield or through the way they are represented in the media. The mass media, therefore, plays a vital role in inter-religious conflicts as an arena for the expression of the various versions of the causes of the conflict. History has shown that the media can incite people towards violence (Jega, 2000; Ibrahim \& Kazah, 2003). For instance, Adolf Hitler used the media to create a worldview of hatred for Jews and other minority groups. Also, according to Sule (2015, p. 199), Rwanda's radio RTLM urged the Hutus to pick up machetes and kill their fellow Tutsis which they referred to as "the cockroaches." Broadcasters in the Balkans polarised local communities to the point where violence became an acceptable tool for addressing grievances. The media's impact on the escalation of conflict is, therefore, more widely recognised than the media's impact on peacebuilding. A common journalist principle is: "If it bleeds, it leads" (www.urbandictionary.com/define). That means that the media loves violence and conflict to form headline news, as against news of dialogue and understanding. This tendency to give priority to conflict and violence news over peace news distorts reality and leads many people to think that conflict is pervasive and peace is abnormal (Kura, 2010; Pew Research Centre, 2010).

Several studies confirm that the impact of the media on conflict escalation is greater than the impact of the media on conflict prevention and peacebuilding. Cited in Sule (2015) peace journalism scholar Gadi Wolfsfeld notes that there is a "fundamental contradiction between the nature of a peace process and news values, the media often play a destructive role in attempts at making peace" (p. 199). Media and media professionals tend to favour four values: immediacy, drama, simplicity and ethnocentrism. These values make it difficult to use the media for peace. As a result of their ability to reach and influence large numbers of people, the media carry immense power in shaping the course of a conflict (Pew Research Centre, 2010).

Furthermore, cited in Salawu (2009, pp. 77-78) Tichenor et al. (1980, p. 17) note that social conflict is a 
principal ingredient of much newspaper content since conflict is a central component in community life and social change. Also cited in Salawu (2009, pp. 77-78) Tehranian (1996, p. 3) explains this further by saying that the media are naturally attracted to conflict. Media Development (1996, p. 2, cited in Salawu, 2009) elaborates: "conflict is the bread and butter of journalism. Conflict sells". Arno and Dissanayke (1984, p. 2, cited in Salawu, 2009) assert, "I would go so far to assert that news is defined by its conflict focus and that there is nothing deplorable about the fact."

The media are justified in reporting conflicts because they have the responsibility of recording events as they unfold, part of which conflict is. In other words, conflict is a part of reality and the media have the task of portraying reality. As Hjarvard, Mortense and Eskjǽr (2015) cited in Abdel-Fadil (2017) note, there are four possible outcomes of media-constructed conflicts: "(1) reduce or resolve conflicts; (2) generate new conflicts; (3) transform existing conflicts; and (4) intensify or prolong conflicts" (p. 461) (see Figure 1). The provision of information about the conflict in the media is a step towards resolution. Tichenor, Donohue and Olien $(1980$, p. 2$)$ provides an insight,

There is the traditional view that the resolution of social problems is related to inputs of information.

Accordingly, if a system is sufficiently saturated with information, a general understanding of the topic will

develop within the system. Once understanding is at hand, a resolution is assumed to be at hand.

Viewed differently, newspapers' and other media's reports of conflict are said to be contributory to the legitimisation of the conflict (Nnaemeka, 1976). Olorunyomi (2000, p. 5), with background knowledge of the genocide in Rwanda, further, contends that the media can act as an accomplice to genocide not only through their indifference but also through active collaboration. He asserts: "In every communal or ethnic conflict, the positions of the media can significantly impact the outcome". Olorunyomi $(2000$, p. 7) again notes that the problem associated with media coverage of diversity or conflict is not normative, but rather ontological. The scholar argues:

To isolate the problems associated with covering diversity as simple matters of norms is to suggest that only endogenous factors influence the practice of the media. The fact of diversity in concrete editorial terms always assumes a pluralism that also includes the exogenous variables of ownership, employees, content and sources (Olorunyomi, 2000, p. 6).

Olorunyomi further posits that the media's capacity to respond to their structural weaknesses would strengthen their capacity to better promote tolerance (resolve conflict), as shown in Figure $1^{2}$ (see Appendix), and help manage diversity in the communities they serve and beyond. Internal diversity in media organisations or not, individual media owners and journalists need to appreciate the tensions between globalisation and primordial feelings and between the notions of totality and heterogeneity (Olorunyomi, 2000, p. 5).

Generally, studies in identity underscore the fact that identity implies similarity and contrast at the same time (Jenkins, 2004; Okpanachi, 2010). For an individual or a group, there may be a plurality of identities. Yet, such a plurality is a source of stress and contradiction in both self-representation and social action. This is because identity must be distinguished from role-sets (Okpanachi, 2010). Recent studies on religious identity have also underscored the positive function of religion in the promotion of peace (see Abdel-Fadil, 2017; Hjarvard et al., 2015). On the other hand, however, mobilisation of identity has been used to incite political groups to struggle and religious groups to legitimise wars and various modes of brutal and violent acts (Alger, 2002, p. 101; Jega, 2000; Okpanachi, 2010) with devastating consequences on both the media and the society (Sule, 2015).

The media are naturally attracted to conflict because conflict is intrinsically linked to journalism so much so that some definitions of news often begin with the term "conflict." Since abnormality makes news and violent conflict is an abnormality, the mass media tend to thrive on conflict as conflict attracts readers, viewers and listeners to the media. The prime news value of the media are sometimes conflict, disorder and negative events as good news stories receive less media attention than bad news (Sule, 2015).

\subsection{Repercussion of Inter-Religious Conflicts on the Media}

The mass media have a special relationship with conflict situations as demonstrated in the literature (see Sule, 2015; Yoroms \& Mu'azu, 2009). This relationship exists because all over the world conflict especially interreligious conflict is of major news value for the mass media and it is a matter of public importance and interest because of its security implications. This relationship goes in many ways. In as much as the mass media is very much interested in inter-religious news and thus can positively or negatively affect inter-religious conflicts, interreligious conflict situations and insecurity do also affect the operations of the mass media in diverse ways (Abdulrahman, 2006; Odukoya \& Çancı, 2016).

There are many perspectives on the issue of the relationship between the mass media and inter-religious conflicts, ranging from the view that a society gets the mass media it deserves, to the argument that the mass media is a mirror that shows what a country is, what its people are and the kind of society in place. Others still explain that the mass media is only a tool which the ruling class uses to protect their interests, advance their cause, and control the society they live in and the people they govern. The mass media according to this view, therefore, is a weapon of further oppression by the ruling class (Yoroms, 2009). 
The output of the mass media outlets depends on the professional, moral and intellectual calibre of the persons owning and manning it as much as their backgrounds, convictions, interests and outlook on life. Journalists are human beings like everyone. However, journalists are expected to be professionals, operating within the provisions of the ethics and the laws governing the profession. The same individuals and events are treated differently by different media outlets. Some take one or the other side in the conflicts and become its spokesmen. Others stoke the fires subtly or not so subtly. Still, others create and depict false incidents to suit their designs (Olojo, 2014; Sule, 2015).

The fact remains that there is crass commercialisation of the mass media. The products of the media are being sold like any other commodity in the market, and most of those who run the media, do it mostly for purely commercial or political interests. The subtle understanding, therefore, is that "anything that pays is welcome." This being the motto of profit-seeking commercial media, the sensationalisation of inter-religious conflict situations are not a taboo, nor false motivated versions of the incidents (Sule, 2015; Umar, 2009).

One of the major areas that inter-religious conflict affects the mass media is that the parties in conflicts try to use the media to further their ends. As a result, the mass media comes heavily under all sorts of undesirable pressures and pulls and also threats. In most cases, the mass media comes under duress and intimidation and the blandishment of these influences. Moreover, inter-religious conflicts like any other conflict are very disruptive of the normal market conditions in which the media operate. The print media, in particular, faces serious production and distribution problems during conflicts. In the past three decades of inter-religious conflicts in Nigeria, many media organisations have closed shops as a result of outright government censure or seizure of printed copies of newspapers or magazines. Inter- and ethnoreligious conflicts also affect advertisers and thus affect the economic fortune of the media organisations (Salihu, 2007).

The media, whether local or international, will always face a considerable challenge in trying to cover conflicts. There will inevitably be commercial pressure to focus on the immediate, most violent or dramatic incidents, at the expense of explaining the background and issues that may underpin the conflict. The mass media faces a lot of problems during inter-religious conflicts as media professionals and members of their families are exposed to various intimidations and violence. In times of conflicts, media professionals are not as safe as they have no place to run to in the discharge of their duties. For instance, the Boko Haram conflict has been responsible for the death of some journalists with several others internally displaced with members of their family (Sule, 2015). This situation adversely affects the work environment of the journalists, their psychology and output in the discharge of their duties (Author, 2020; Author \& Hassan, 2017; Warner \& Matfess, 2017).

During inter-religious conflicts, the economic situation of media organisations is precarious because the infrastructure upon which the media depends - reliable power supply, transport network, equipment- are likely to be destroyed or damaged. This, of course, affects the performance of the mass media adversely. Also, during interreligious conflicts, newspapers and news magazine organisations loss huge revenue sources when they could not sell their copies due to government seizure or insecurity which compels newspaper vendors to abandon their duty posts. This too is capable of driving media organisations out of business (Moemeka, 1985).

Another area inter-religious conflicts especially insurgency affects the media is the area of intimidation and destruction of media establishments (Mu'azu, 2011). A typical case in point was when on 26th April 2012 Boko Haram bombed some media houses for under-reporting them. According to the report:

Boko Haram on Thursday explained that its grouse with 'ThisDay' over alleged misrepresentation of its position and perceived bias led to the bomb attacks on its offices in Abuja and Kaduna.... Suspected Boko Haram members bombed 'ThisDay's' Abuja office as well as a complex housing 'ThisDay', 'The Sun' and 'The Moment' newspapers in Kaduna, leaving many people dead and many more injured. The sect also is known as Jama'atu Ahlis Sunna Lidda'awati Wal Jihad said in an interview with a website, premiumtimesng.com, that it was targeting Nigerian and foreign journalists. (Yahaya, 2011, n.p.).

In their attempt to intimidate and cow the media Boko Haram boasted further that:

It is not only 'ThisDay' that has been engaged in a negative media campaign, fictional stories and constantly promoting fake stories by the JTF to give an impression that they are making headway against us; yet there is no time the media investigated further as an objective and responsible bystander in this war. But the sins of 'ThisDay' are more.... They once insulted the Prophet Mohammad in 2001 and we have not forgotten... (Ndujihe, 2013).

The Nigerian media since these series of bomb explosions have been operating under a very dangerous environment. Most of them have removed their signboards and have gone underground in their operations. This has adversely affected the psychology and morale of the media professionals who have to be more careful in carrying out their duties to society (Sule, 2015).

Another major area that inter-religious conflicts affect the mass media is free to access of media professionals to the areas of conflicts, mobility and safety during conflict situations in discharging their duties and reasonable access to official information. If all these requirements are denied, then obviously media professionals cannot do their jobs. If access to official information and access to the conflict areas are made possible, the quality of news 
coverage is again heavily dependent on the honesty and cooperation of official sources (Salawu, 2009; Sule, 2015).

Not only that, but the prolonged inter-religious conflicts that have plagued this country for over three decades have also adversely exposed the fact that the media professionals were mostly influenced by their ethnic and religious divides. Their professional ethics were jettisoned in favour of parochial, ethnic, religious, ideological, political and commercial interests. The rise of religious sentiments and the urge to defend "one's religion" has coloured the way news about religious crises are reported in the Nigerian mass media. During inter-religious conflicts in the country, the news that one reads in newspapers and magazines and listens to over the radio and on television are as varied as the state of faith of the reporters. To properly propagate, articulate and defend their religious views, many religious organisations in some instances establish their media outfits. Therefore, from these few examples, it is clear that in as much as the mass media influence conflicts situations, conflict, in turn, do affect media operations adversely (Ibrahim \& Kazah, 2003), which affects social, economic and political development in turn (Jega, 2000).

\subsection{Repercussion of Media Creation of Inter-Religious Conflicts on National Development}

The mass media as the watchdog of society plays enormous roles in national development. National development, on the other hand, involves changes or advancement in a nation aimed at improving the political, economic and social lives of the people. National development, therefore, is a multidimensional concept that involves every segment of the nation's life. However, violent inter-religious conflicts constitute great challenges to national development because inter-religious conflicts destroy lives, property, and the environment. The nexus between national development and violent inter-religious conflict, therefore, cannot be overemphasised (Sule, 2015; Oluwatoyin \& Tolu, 2011).

Violent inter-religious conflicts severely compromise the skills and assets that are essential to living a productive life and discourage planning and investment opportunities thereby leading to acute poverty. Areas experiencing high rates of violent inter-religious conflicts tend to experience declining levels of progress concerning human development as measured by poverty and income. Persistent violent conflicts lead to acute poverty, high rate of unemployment and hunger. The effects of conflicts on national development have been enormous. These conflicts have affected men and women and boys and girls in different ways. These conflicts also have adverse repercussion on development in all ramifications (Jega, 2000; Sule, 2015; Oluwatoyin \& Tolu, 2011).

3.2.1 Repercussion on Social Development

The social repercussion or effects of inter-religious conflicts cannot be overemphasised. Incessant inter-religious conflicts have continued to threaten the socio-economic development, peace, unity and stability of Nigeria in the past three decades. Inter- and inter-religious conflicts have equally, adversely affected the existing social relationships between neighbours that were hitherto living peacefully. These conflicts have further negatively increased inter-religious consciousness among Nigerians and have led to hatred, enmity and persistent suspicions among the adherents of Islam and Christianity (Author, 2020; Author \& Hassan, 2017).

In Nigeria nowadays, inter-religious consciousness has led to various social ills ranging from problems of inter-religious influence on job recruitments, promotions and securing admission to schools. Also, projects like road constructions, schools, electricity, waterworks, health centres and other projects were either frustrated or sited in wrong places as a result of inter-religious influences (Sule, 2015).

In the area of education, due to frequent disruption and closure of schools during inter-religious conflicts in some parts of northern Nigeria, the educational quest of the children has been adversely affected and retarded. Apart from this, schools, students/pupils and their teachers were not spared during inter-religious conflicts. Many schools had been burnt down while many were forced to close down for months thus affecting the schools' calendars (Author, 2020; Sule, 2015).

Inter-religious conflicts affect children, girls and women in various ways. Death of men during violent conflicts raise the proportion of female-headed households. After each round of inter-religious-conflict, women tend to face a much heavier burden of caring for their various families alone. Some of the deaths during violent conflicts occur as a result of preventable communicable diseases but because public health programmes such as immunisation for disease control and prevention cannot be carried out during violent conflicts. This has implications for the health of the citizens in the conflict areas. Also, the adverse effects of violent inter-religious conflicts on women and girls' reproductive and sexual health cannot be overemphasised. This is because their psychological, reproductive and overall wellbeing is often greatly compromised during violent conflicts (Author, 2020; Sule, 2015).

Violent inter-religious conflicts tend to increase the risks of sexual violence on women and girls; rape and sexually transmitted deceases. Aside from this, health facilities are greatly disrupted during violent conflicts. The specific experience of women and girls in violent conflicts is linked to their status in societies. As noted in paragraph 135 of the Beijing Platform for Action, "while entire communities suffer the consequences of armed conflict and terrorism, women and girls are particularly affected because of their status in society and their sex" 
(Sule, 2015, p. 211).

During the violent inter-religious conflict, severe mental and social stress can be caused by deaths, separation and loss of family and friends; loss of home and social environment; exposure to violence, including witnessing or directly experiencing rape, torture and the killing of friends or relatives. So also the weakening or severing of family and community bonds, networks and material deprivation. Another major social effect of inter-religious conflicts is the displacement of women and girls as internally displaced persons. In conflict situations, adults too need protection and are, therefore, less able to support and defend their families (Abdulazeez, 2017; Warner \& Matfess, 2017).

3.2.2 Repercussion on Political Development

The constant incidences of inter-religious conflicts in Nigeria in the past three decades have contributed to overheating the nation's politics and political processes as the country is being constantly threatened with disintegration and separatism. This tensed political situation has become more severe as adherents of each of the two dominant religions in Nigeria, Islam and Christianity try to dominate the political landscape using ethnicity and religion as instruments for bargaining. The question now becomes, is he a Muslim or Christian President, Minister, Governor or Local Government Chairman? The consequent abuse of basic human rights following these inter- and inter-religious conflicts cannot go unnoticed (Pate \&Author, 2020; Sule, 2015).

In the face of political instability following these persistent inter-religious conflicts in the past three decades, some Nigerians were forced to relocate to their states of origin and even to their communities for safety. Apart from this, government policies are influenced by emotional sentiments and manipulation of inter-religious cleavages. Right from the formation of political parties to electioneering campaigns and voting patterns, all are being influenced by inter-religious tendencies and affiliations. As a result of this, politics in Nigeria is always volatile and usually leads to violence and the destruction of lives and property (Author, 2019; Jega, 2000; Sule, 2015).

3.2.3 Repercussion on Economic Development

Inter-religious conflicts have a lot of economic consequences. Conflicts in whichever form, lead to unemployment and loss of income because of disruption of economic activities, infrastructure, uncertainty, increased cost of doing business, and capital flight. Furthermore, during conflicts, social spending is often reduced to accommodate increased security spending as the economy undergoes structural changes (Anderson, 2010).

Violent inter-religious conflicts have adverse effects on the economy of any society or nation from which recovery may take many years. Inter-religious conflicts retard economic progress, hamper economic activities and consequently lead to unemployment and poverty. Inter-religious conflicts equally disrupt small and medium scale and other commercial activities. They destroy the lives of able-bodied men and women who would have engaged in productive activities to contribute to the economic development of the nation or community (Sule, 2015).

Furthermore, violent conflict, whether inter-religious, political or otherwise can destroy everything, from people, crops, infrastructures and other material resources to institutions, including education, political will, hope, and trust. Violent conflict causes poverty, suffering and is disastrous to the economic development of any community and nation. Violent conflict in whatever form affects and reverses development efforts. Inter-religious violent conflicts destroy lives, property, and the environment and as such, it is developmental in reverse (Mu'azu, 2011). The nexus between the development of a nation and violent conflict, therefore, cannot be overemphasised. National development is a multidimensional concept that involves every segment of the nation's life. Interreligious violent conflict constitutes an extraordinary challenge to national development. Irrespective of where inter-religious violent conflict occurs, victims and survivors are likewise affected by pain, suffering and trauma even long after the conflict stops. Inter-religious violent conflict severely compromises the skills and assets that are essential to living a productive life and shortens planning and investment opportunities (Author, 2020; Sule, 2015).

Countries with low inter-religious conflict tend to make more rapid human development gains than countries with higher violent conflict rates. Areas experiencing high rates of Inter-religious conflict tend to experience declining levels of progress concerning human development as measured by poverty and income. Incessant interreligious conflicts bring about extreme poverty, youth unemployment and increase hunger (Sule, 2015). In Nigeria, unless the incidences of violent inter- and inter-religious conflicts are reduced the country is likely to be found in a cycle of economic decline. The political and social legacy of violent conflicts is usually miserable. Both political rights and health states do not only deteriorate during violent conflicts but are usually persistently made worse. Even after a decade of peace people would hardly have recovered to their pre-conflict levels (Author, Gujbawu \& Abba-Aji, 2019).

The most common legacy is more conflict. Violent conflict digs a deep hole in the economy from which it takes many years to recover. Indeed, many of the costs of violent conflict occur after it is over. Thus, the costs of violent conflicts are very largely not borne by those responsible for them: they are borne by non-combatants but the innocent future inhabitants, and by neighbours. The mass media in Nigeria therefore, have very important roles to play in the incessant inter-religious conflicts that have notoriously become so regular in the country since 1979. 
This growing recognition of the crucial role of the mass media in times of conflict and which in turn affects national development has led scholars to examine how the media can play a constructive role in conflict management and peace-building (Sule, 2015; Warner \& Matfess, 2017).

Inter-religious conflicts have scared investors from investing in Nigeria as conflict-prone environments are not suitable for investments. Incessant inter-religious conflicts have also affected the nation's income and "so many man-hours that would have been used for productive purposes have been lost during violent conflicts in several parts of the country, especially the northern parts of the country" (Sule, 2015, p. 239).

In January 2012, the National Bureau of Statistics (NBS) in its publication titled "Nigeria Poverty Profile 2010 " came out with a report concerning poverty indices in various states in Nigeria from 1980 to 2010. The NBS study shows that whereas there is a general increase in poverty levels all over the nation the poverty level of the states in the northern block is higher when compared with other states of the federation. This also coincided with the period of crises recorded in the Northern part of the country. The nexus between violent conflicts, lack of development, increases in the poverty rate, crimes and further violent conflicts is strong and goes in various directions. This is because violent conflict retards development and lack of development substantially increases proneness to violent conflict and poverty. So also, lack of sensitivity on the part of the media can generate or escalate conflict (Hjavard et al., 2015; Salawu, 2010, 2009; Sule, 2015) (refer to Figure 1).

\section{The Media as an Instrument of Inter-Religious Conflicts Resolution}

The rapid innovations in information and communication technology (ICT) and the mass media of communication have transformed how information is collected and disseminated. The media have been the singular most powerful tool of influence, mobilisation and shaping of political, religious, economic and cultural agendas and discourse in Nigeria and all over the world (Author \& Hassan, 2017). As witnessed many decades ago, such as in the case of the World War II and the subsequent wars of the later century, the use of media propaganda to mobilise a nation, a group or region is just as prevalent today as it was then (Jega, 2000; Sule, 2015). The media today are a leader in their own accord; their influence surpasses that of any other institution. Therefore, the media must maintain an attitude as a neutral watchdog of the society; one that is free of biases and has accountability for the news, publications, images and photographs that profile events, their causes and effects (Iruonagbe, 2009).

In this regard, given the influence the media possess, it should be an instrument that focuses on their ability to resolve conflicts of whatever type in various parts of this country. During inter-religious conflicts, there has been an attempt to understand, accept and create a dialogue between people of various faiths. The global media can be the most influential channels in which this can be accomplished (Iruonagbe, 2009; Sule, 2015).

In the recent inter-religious clashes Muslims and Christians in this country, especially in the North citing examples such as those that occurred in Taraba, Plateau and Kaduna States including the 11-year old Boko Haram insurgency, which has sparked skirmishes between Muslims and Christians with Christians blaming Muslims for the group's insurgency and Muslims claiming that the insurgents (though claim being Muslims) have killed more Muslims than people of other faiths in the country since 2009 (Author, 2020: Author \& Hassan, 2017; Mu'azu, 2011), there has been a misconstrued understanding of the religion and its teachings (Fayemi, 2011; Sule, 2015; Warner, 2012), which is a huge chasm that further creates tension between the adherents of the two main faiths.

To be able to manage such tension, media practitioners ought to be mandated to possess a rudiment understanding of the basics of each religion. For instance, if journalists, editors and media managers and proprietors understand that Islam unequivocally respects other faiths and urges Muslims to follow suit and vice versa for Christianity, media narrative might have focused on uniting the people rather than creating divisions among them on the lines of faith rather than emphasising that neither religion advocates violence against people of other beliefs (Iruonagbe, 2009; Sule, 2015). From the Islamic perspective, for example, the Holy Qur'an says:

Those who believe [in the Qur'an] (Muslims), and those who follow the Jewish (scriptures), and the

Christians, and the Sabians - whoever among them believes in Allah (God) and the Last Day and works

righteousness, shall have their reward with their Lord (God); on them shall be no fear, nor shall they grieve.

(Qur'an chapter 2, verse 62)

To deny the verses stated above, would be the denial of Islam and God, the Creator. Therefore, it must be reiterated that if a Muslim perpetuates acts of violence against people of other faiths, it would be a violation of the Islamic faith and consequently, they are not considered pious Muslims, but as sinners (Haque \& Hossain, n.d.). While from the Christianity perspective, the Bible says, "Strive for peace with everyone" (Hebrews, chapter 12, verse 14).

In essence, just as an act of violence by a group of people who claim to be Muslims or Christians cannot be generalised upon the entire Muslim or Christian population, society or nation, it should be noted that isolated acts of violence by extremists among the adherents of either religion cannot be blamed upon a population of about 200 million Muslims and Christians spread across the vast breadth and length of Nigeria. It is the media's responsibility as an instrument of crisis management and conflict resolution to emphasise that, for example, through agendasetting narratives. This can be mandatory as the media nowadays have the absolute power over all other institutions 
of religion, politics, societies and culture. Their influence and role are those of a universal guardian - an institution that formulates religious, cultural, social and political values. Their role must be played in a positive direction; one of unity and the advocator of the unity of all religions and faiths (Haque \& Hossain, n.d.; Sule, 2015).

However, the media may not have created the conflict, but rather provided the climate for the conflict to be instigated. It is argued that religious and political leaders are the actual proponents of the conflicts, not the media (Egwu, 2001; Salawu, 2009). For example, many people who got involved in the various inter-religious conflicts because of misinterpretation of media reports or because of the media's lack of understanding of how to handle religious-sensitive reports such as the ThisDay newspaper story in $2002^{3}$. Many of the people who got involved in such conflicts are arguably street hooligans, jobless and semi-educated or un-educated youth. They might have been instigated by political and religious zealots for their personal so-called religious and political interests (Ibrahim \& Kazah, 2003; Sule, 2015). The point emphasised here is that the mass media do not have the allpowerful effect of goading people to violence. The Multi-Step Flows Model of mass communication in which the opinion leaders are very influential can explain how the violence came about (See Severin \& Tankard, 1992, pp. 247-266 for discussion on Mass Communication Effects).

In all cases of religious violence in Nigeria, the religious leaders and political elites have always been argued as the propelling forces. Religious violence becomes more devastating when it is perpetrated along ethnic lines. In Nigeria, due to its configuration as a nation, the strand of religion is usually intertwined with that of ethnicity (Salawu, 2010, p. 258). The ethnicisation of religion is reflected in the fact that "whenever there is a religious uprising, peoples from different parts of the country are always at each other's neck" (Salawu, 2009, p. 258).

The media get involved in this religious drama. Nigerian newspapers, variously, narrate the stories and comment on such conflicts based on their publishers', editors' or reporters' religious and ethnic background. The religious and or ethnic identity of a Nigerian newspaper is determined by the location of its headquarters, the religious or ethnic identity of the publisher (Uduak, 2000, p. 78) and the main market that the paper seeks to cultivate and patronise (Abati, 2000, 91-92; Salawu, 2009, pp. 258-259). For instance, the way 'New Nigerian' and Daily Trust, both are northern-based national newspapers will narrate and comment on the events of the religious riots will be different from the way New Tribune and 'The Punch', both are southern-based and owned by Southerners will do the same. The issue is even more apparent with indigenous language newspapers. Indigenous language newspapers are ethnic-based newspapers, which of course, have primordial interests in the ethnic groups whose (indigenous) languages the newspapers use. These newspapers can lead and modify the opinions of their peoples, forming stereotypes for them about other ethnic groups, thereby fuelling further the social (religious and ethnic) conflicts (Abdel-Fadil, 2017; Hjarvard et al., 2015; Jega, 2000; Salawu, 2010, 2004).

The expectation here is that in the spirit of secularisation, Muslims and Christians must learn to tolerate one another's viewpoints as it relates to social, economic, legal and political issues. Issues of revenue allocation and equitable distribution of resources should be addressed by the government as this has dominated religious programming. In the interest of public safety and peace, the media must be careful in terms of how crisis events are reported to reduce elements of escalation. It is not proper to use religion to destroy one another. Love and peace must be allowed to reign in the lives of the people). It is necessary to always remember that there is the law of retributive justice, because what a person sows, that they would surely reap (Yoroms \& Mu'azu, 2009).

While it is true that objectivity as a hallmark of good journalism is relative, the media should be able to balance the tension between primordial feelings and national cohesion; and between press freedom and social responsibility. Media practitioners - especially journalists, reporters, editors and media proprietors - should possess at least basic understanding of the tenets of the religions professed by most Nigerians (Islam and Christianity); they should apply their knowledge of the basics of the main religious with their experience and publish religious violence-free news and information for the sake of national cohesion, development; for the sake of peace and sake of the one God both Muslims and Christians worship (Omorogbe \& Omohan, 2005; Said, 1997). Unless the complexity of violent conflicts is discovered and understood, no meaningful conflict management can be achieved. Therefore, it becomes important to look at the mass media as one of the institutions in conflict management and to investigate how their activities might contribute to the escalation or de-escalation of religious conflicts in Nigeria, especially in northern Nigeria and its effects on national development (Mu'azu, 2011; Sule, 2015).

What have been the roles of the mass media in the perpetuation or resolution of these conflicts? In other words, do the mass media affect religious conflicts in Nigeria? According to Yoroms and Mu'azu (2009):

Conflicts often generate media attention because they fit into the definition of what is considered news by professional journalists: timeliness, unusualness, drama, consequence and proximity, and the involvement of personalities who become important definers of the conflict. These elements help the media to define news in negative terms, and conflicts tend to provide the raw material that fits this definition. (p. 10) Hjarvard et al. (2015) and Abdel-Fadil (2017) also agree with Yorom and Mu'azu's argument.

\section{Conclusion and Recommendations}


So far, attempts have been made to discuss the adverse effects of inter-religious conflicts in Nigeria, especially in the past three decades, from 1990 to 2020 . Grounded in the mediatisation theoretical perspective, this paper concludes that inter-religious conflicts are protracted, widespread, complicated and dangerous forms of conflicts plaguing Nigeria today, especially the northern part of the country. These conflicts have lingered on for the past three decades without solutions in sight. The aftermaths of these conflicts led to the destruction of lives and property, physical and mental devastation, deprivation and dislocation of many Nigerians.

The mass media's roles in escalating or deescalating these incessant conflicts have been questioned by scholars and non-scholars alike. The literature has shown that the general knowledge of journalism is not enough for most media professionals to report inter-religious conflicts effectively. As a result, the consequence can be a reporting style that feeds on and repeats the worst stereotypes, the drama and the immediacy of conflict, and fuels their ignition into violence as the finding of a study on media reportage of ethnoreligious conflicts in northern Nigeria conducted by Sule (2015) has shown. The mass media, therefore, can overcome many of the challenges of reporting inter-religious conflicts when they understand the psychology and the emotion involved in ethnic and religious issues. Once media practitioners (journalist, reporters, editors, managers and programme producers and presenters) can understand various issues and intricacies of inter-religious conflicts, they will engage in objective and responsible reportage for a peaceful society which will lead to national development.

Therefore, peaceful co-existence among adherents of various religions in Nigeria, especially Muslims and Christians, can best be promoted by the mass media for national development. National development, on the other hand, cannot take place in the face of incessant violent inter-religious conflicts with their attendant destruction of lives and property. That is why the mass media as a pivotal institution in the society should carry out their functions responsibly towards a peaceful society.

Finally, in furtherance of research toward understanding the relationships between the media and religion in the Nigerian context, this paper proffers the following propositions for consideration for investigation in future research:

1. Ethnic identity, political identity and religious identity could influence media narrative of violent interreligious conflicts in Nigeria;

2. There could be a strong correlation between escalation and de-escalation of ethnoreligious conflict by the nature of mass media reportage for national development;

3. Bearing the enormous power of the mass media, if this power is employed positively, it will certainly act as a good facilitator of the conflict resolution process. Therefore, in times of violent conflicts, the media have an additional social responsibility regarding what to report, what not to report, and how to report; and

4. Issues of protracted incidences of violent inter-religious conflicts have a very wide area of research in Nigeria and Africa South of the Sahara. While much has been written on their causes or origins and the way forward, no serious attention is given to the study of the effects of media created inter-religious conflicts and their implications for national development.

\subsection{Recommendations}

Bearing in mind the literature and the reality of violent inter-religious conflicts in Nigeria in the past three decades and the attendant effects on national development, all institutions in Nigeria should perform their functions responsibly for national development. The mass media should do much more than reporting conflicts from a distance. The mass media must be involved in deliberate peace-making through their reportage for a peaceful society.

Therefore, to ensure peace, unity and social equilibrium for national development in a pluralistic society like Nigeria, this paper recommends that religious leaders should endeavour to give proper teachings and interpretations of their religious tenets and dogmas to their followers to avoid religious extremism and fundamentalism. Because of globalisation, the world has become a global village. This has brought about the influx of extremist religious influences from outside of Nigeria. The government should monitor the influx of extremist religious literature and teachings that are capable of radicalising our youths and thus making them prone to religious violence.

As a pluralistic society, the mass media while reflecting this plurality and diversity of opinions should report with sensitivity, inter-religious issues that are capable of destabilising and therefore affecting national development. Journalists handling religious bits should be made to acquire adequate knowledge of the major religions in Nigeria. They should note the basic beliefs and practices of the religions, especially Islam and Christianity. Taboos of these religions should be noted so as not to encroach on them like the case of ThisDay newspaper and the Miss World Beauty Pageant which occurred in 2002. The mass media need to avoid the use of gory pictures and sensational headlines and the use of inflammatory and derogatory language, especially when reporting inter-religious issues. For instance, "these are the bodies of the 300 Christians or Igbos killed in Kano," instead of "these are the bodies of 300 people killed in Kano." 
International media organisations should engage more reporters on a full-time basis and not rely on stringers who are paid based on the number of stories published as they have done over the years. Religious, political, ethnic and other leaders should stop using religion and ethnicity for their selfish ends to avoid inter-religious conflict to ensure unity and national development. All media practitioners and managers should be mandated to have some form of training/symposiums on understanding the rudiments of both Islam and Christianity to curtail poor handling of religious-sensitive news stories, information and other media contents. It is also recommended that caveats on publishing/reporting religion should be printed as pamphlets and hung in every newsroom while mobile journalists should be provided with its electronic copy in their mobile devices for reference purposes in addition to the training/symposiums mentioned above. Finally, future research should explore the propositions proffered above to develop them into hypotheses and test them as a furtherance of exploring a lasting solution to the lingering inter-religious conflicts in Nigeria from empirical research perspectives.

\section{References}

Abdel-Fadil, M. (2017). Identity politics in a mediatised religious environment on Facebook: Yes to wearing the cross whenever and wherever choose. Journal of Religion in Europe, 10, 457-486. doi: 10.1163/18748929. 01004001

Abati, R. (2000). The press, politics and society in Nigeria. T. Oseni \& L. Idowu (Eds.), Hosting the 140th anniversary of the Nigerian press. Lagos: Tosen Consult.

Abdulazeez, M. A. (2017). The inadequacies of exclusive military action: Countering Boko Haram's terrorism with alternative approaches. In Selected papers: Terrorism experts conference (TEC) 2016 (pp. 26-60). Brussels: NAT.

Abdulrahman, D. (2006). Ethnicity, leadership and national integration in Nigeria, in H. A. Saliu, A. Jimoh \& T. Arosanyin (Eds.), The national questions and some selected topical issues on Nigeria (pp. 121-132). Ibadan: Vantage Publishers.

Alger, C. F. (2002). Religion as a peace tool. The Global Review of Ethnopolitics, 1(4), 94-109.

Arno, A. \& Dissanayke, W. (1984). The news media in national and international conflict. London: A Westview Special Study.

Atanda, J. A. (1989). Nigeria since independence: The first 25 years. Jericho: Heinemann Educational Books Nig. Ltd.

Author (2020 September, in press). Boko Haram's feminization, minorization and cyberization of terrorism: Offering cyberterrorism diffusion model as anti-Bokoharamism tool. In M. Khosrow-Pour (Ed.), Encyclopedia of information science and technology, 5th ed. (060818-125903). Hershey: IGI Global.

Author (2019 July - Dec.). Theorizing the journalism model of disinformation and hate speech propagation in a Nigerian context. International Journal of E-Politics, 10(2), 60-73. doi: 10.4018/IJEP.2019070105

Author \& Hassan, M. S. (2017). Media versus Boko Haram: Proposing the adoption and use of cyber technology by terror group's model for counterinsurgency. Beau Bassin, Mauritius: Lambert Academic Publishing, ISBN: 978-620-2-01806-7.

Author, Gujbawu, M. \& Abba-Aji, N. (2019). Enough is enough of this conflict. Peace is all we want! Advocacy for mediatization and digitization of de-bokoharamization campaign. In J. A. Opara (Ed.), Outlook on human capacity building and development: A handbook of research in honour of Professor Ibrahim Njodi (pp. 111130). Maiduguri: University of Maiduguri Press.

Dike, V. E. (2005). Corruption in Nigeria: A new paradigm for effective control. Africa economic analysis. [Online] Available: http://www.africaeconomicanalysis.org/articles/gen/corruptiondikehtm.html [July 25, 2016].

Egwu, S. (2001). Ethnic and religious violence in Nigeria. Jos: African Centre for Democratic Governance (AFRIGOV).

Ekundayo, J. M. O. (2013). Out of Africa: Fashola reinventing servant leadership to engender Nigeria's transformation. Bloomington: AuthorHouse.

Ekoko, A. E. \& Amadi, L. O. (1989). Religion and stability in Nigeria. In J. A. Atanda, S. Garba \& Y. Abubakar (Eds.), Nigeria since independence: The first 25 years. Lagos: Heinemann.

Fayemi, K. (2011). Boko Haram can consume us. Tell magazine, 26 September 2011.

Haque, F. \& Hossain, M. K. (n.d.). Global media, Islamophobia and its impact on conflict resolution. Working Group: Islam and Media, Institute of Hazrat Mohamamad (SAW), Banani, Dhaka, Bangladesh. [Online] Available: http://www.ihmsaw.org/resourcefiles/1260034024.pdf [May 27, 2020].

Hjarvard, S. (2011). The mediatisation of religion: Theorising religion, media and social change. Culture and Religion: An Interdisciplinary Journal, 12(2), 119-135.

Hjarvard, S., Mortensen, M. \& Eskjǽr, M. F. (2015). Three dynamics of mediatised conflicts. In M. F. Eskjǽr, S. Hjarvard \& S. Mortensen (Eds.), The dynamics of mediated conflicts (pp. 1-27). New York: Peter Lang.

Ibrahim, J. \& Kazah, T. (2003). Ethno-religious identities in northern Nigeria. Uppsala: Nordic Africa Institute. 
"If it bleeds, it leads." [Online] Available: https://www.urbandictionary.com/define.php? [September 6, 2012]. Ilesanmi, S. O. (1997). Religious pluralism and the Nigerian State. Athens, O.H: Ohio University Press.

Iruonagbe, T. C. (2009). Religion and its attendant conflicts in Nigerian: A paradox. International Journal of Theology \& Reformed Tradition, 1, 152-168.

Jega, A. (2000). General introduction: Identity transformation and the politics of identity under crisis and adjustment. In A. Jega, Attahiru (Ed.), Identity transformation and identity politics under structural adjustment in Nigeria (pp. 11-23). Stockholm: Nordic Africa Institute and Centre for Research and Documentation.

Kura, K. H. (2010). Muslim-Christian cooperation for conflict prevention/management, peacebuilding and reconciliation in northern Nigeria. A paper delivered at a conference on Muslim-Christian Cooperation...in...states of Nigeria. 6th-9th Oct. 2010, Kaduna, PCMRA. [Online] Available: https://www.procmura-prica.org/files/Kaduna Report.pdf? [July 24, 2016].

McQuail, D. (1979). The influence and effects of mass media. In J. Curran, M. Gurevitch \& J. Woolacott (Eds.), Mass communication and society (pp. 70-93). Thousand Oaks: Sage.

Media Development. 'Editorial', 4, Vol. XLIII. 1996.

Moemeka, A. A. (1985). Communication in national development: The use of the mass media in rural development. Informatologia, Yugoslavika, 17(1-2), 171-85.

Mu'azu, A. (2011). Understanding the emerging trends of terrorism in Nigeria: A case study of Boko Haram and similar groups. In Responding to emerging trends of terrorism in Nigeria (pp. 10-21) Conference proceedings, monograph series 16. Lagos, CLEEN Foundation. [Online] Available: http://www.cleen.org/Responding\%20to $\% 20$ the $\% 20$ Emergining\%20Trends $\% 20$ of $\% 20$ Terrorism $\% 20 \mathrm{in} \% 20$ Nigeria.pdf [July 25, 2016].

NBS (2010). Nigeria poverty profile 2010. National Bureau of Statistics (NBS), Abuja, Nigeria, Jan. 2012.

Ndujihe, C. Timeline of Boko Haram clashes with the State. Vanguard [Lagos], April 52013.

Nnaemeka, T. I. (1976). Issue legitimation, mass media functions and public knowledge of social issues (unpublished doctoral dissertation), University of Minnesota.

Odukoya, O. A. \& Çanc1, H. (2016). Ethnic and religious crises in Nigeria: A specific analysis upon identities (1999-2013). AJCR, 1. [Online] Available: https://www.accord.org.za/ajcr-issues/ethnic-religious-crisesnigeria/ [May 27, 2020].

Odiase-Alegimenlen, O. A. (2001). Consequences of an unbalanced political system - A social-legal perspective to conflict in the Nigerian state. Nigerian Journal of International Affairs, 27(1 and 2), 47-62.

Ogbeidi, M. M. (2012). Political leadership and corruption in Nigeria since 1960: A socio-economic analysis. Journal of Nigeria Studies, 1(2), 1-25.

Olojo, A. E. (2014). Muslims, Christians and religious violence in Nigeria: Patterns and mapping (June 2006May 2014). IFRA-Nigeria working papers series, no. 33, pp. 1-44. [Online] Available: http://www.ifranigeria.org/IMG/pdf/muslims-christians-religious-violence-nigeria.pdf [July 25, 2016].

Olorunyomi, D. (2000). Conceptual issues in media and conflict. Covering diversity: A resource and training manual for African journalists. Washington: The Panos Institute; New York: Centre for War, Peace and the News Media; Lagos: Independent Journalism Centre.

Oluduro, O. (2010). The role of religious leaders in curbing the spread of HIV/AIDS in Nigeria. Potchefstroom Electronic Law Journal, 13(3), 207-236.

Oluwatoyin, A. \& Tolu, L. (2011). National development in Nigeria: Issues, challenges and prospects. Journal of Public Administration and Policy Research, 3(9), 237-241.

Okpanachi, E. (2010). Ethno-religious identity and conflict in Northern Nigeria (IFRA) (Institut de Recherche français en Afrique) e-papers. [Online] Available: http://www.ifra-nigeria.org/publications/ifra-epapers/article/eyene-okpanachi-2010-ethno? [July 11, 2016].

Omorogbe, S. K. \& Omohan, M. E. (2005). Causes and management of ethno-religious conflicts: The Nigeria experience. In A. M. Yakubu, R. T. Adegboye, C. N. Ubah \& B. Dogo (Eds.), Crisis and conflict management in Nigeria since 1980 (Vol. II) (pp. 557-558). Kaduna: Nigeria Defence Academy.

Osaghae, E. E. \& Suberu, R. T. (2005). A history of identities, violence, and stability in Nigeria. CRISE working paper No. 6. Oxford Centre for Research on Inequality, Human Security and Ethnicity. [Online] Available: http://r4d.dfid.gov.uk/PDF/Outputs/Inequality/wp6.pdf [July 14, 2016].

Pate, U. A. \& Ibrahim, A. M. (2020). Fake news, hate speech and Nigeria's struggle for democratic consolidation: A conceptual review. In A. M. G. Solo (Ed.), Handbook of Research on politics in the computer age (pp. 89112). Hershey: IGI Global. doi: 10.4018/978-1-7998-0377-5.ch006

Pew Research Centre (2010). Tolerance and tension: Islam and Christianity in Sub-Saharan Africa. [Online] Available: http://www.pewforum.org/files/2010/04/sub-saharan-africa-appendix-b.pdf [July 13, 2016].

Said, E. W. (1997). Covering Islam: How the media and the experts determine how we see the rest of the world. New York: Vintage Books. 
Salawu, B. (2010). Ethno-religious conflicts in Nigeria: Causal analysis and proposals for new management strategies. European Journal of Social Sciences, 13(3), 345-353.

Salawu, A. (2009). Media narrative construction of ethno-religious conflicts in Nigeria. Estudos em Comunicação, $5,75-93$.

Salawu, A. (2004). Identity politics and the indigenous language press: A case study of the Alaroye Publications. In O. Duro et al. (Eds.) Nigeria and globalisation: Discourses on identity politics and social conflict. Lagos: CBAAC.

Salihu, A. (2007). Making the media relevant in conflict management and peace building. In A. Saidu \& C. Best (Eds.), Pens and peace (pp. 35-48). International Centre for Reconciliation, Coventry Cathedral, Centre for Conflict Management and Peace Studies, University of Jos, Nigeria.

Severin, W. J. \& Tankard Jr., J. W. (1992). Communication theories: Origins, methods and uses in the mass media. New York: Longman.

Sule, R. N. (2015). Ethno-religious conflicts, mass media and national development: the northern Nigeria experience (unpublished doctoral thesis), University of Jos, Nigeria.

The Holy Bible.

The Holy Quran.

Tichenor, P. J. \& Donohue, G. A. \& Olien, C. N. (1980). Community conflict and the press. London: SAGE Publications.

Toure, M. (2012 October). Conflict resolution in Islam. Speech in Portland, OR.

Uduak S. (2000). Reporters as ethnic messengers. Covering Diversity: A resource and training manual for African journalists. Washington: The Panos Institute; New York: Centre for War, Peace and the News Media; Lagos: Independent Journalism Centre.

Umar, M. (2009). The broadcast media and conflict management in Nigeria. In J. Yoroms \& A. Mu'azu (Eds.), Conflict management and the media in Nigeria (pp. 73-97). Kano, Centre for Research and Documentation (CRD).

Yahaya, D. (2011). Phenomenon of Boko Haram in Nigeria. Paper presented at the National Conference of Resource Forum of the Islamic Movement in Nigeria at Baqiyatullah Husainiyyah, Zaria, 16th of Oct. 2011.

Yoroms, J. \& Mu'azu, A. (Eds.). (2009). Conflict management and the media in Nigeria. Kano: Centre for Research and Documentation (CRD).

Warner, J. \& Matfess, H. (2017). Exploding stereotypes: The unexpected operational and demographic characteristics of Boko Haram's suicide bombers. Washington DC: Combating Terrorism Center at West Point.

Warner, Z. (2012). The sad rise of Boko Haram. New African, 01 April, pp. 38-40.

Yoroms, J. (2009). The state, the media and conflict management: A conceptual approach. In J. Yoroms \& A. Mu'azu (Eds.), Conflict management and the media in Nigeria. Kano, Centre for Research and Documentation (CRD). 


\section{Appendix}

A

\section{Generate new types of conflict}

I.

\section{Reduce or resolve conflicts}

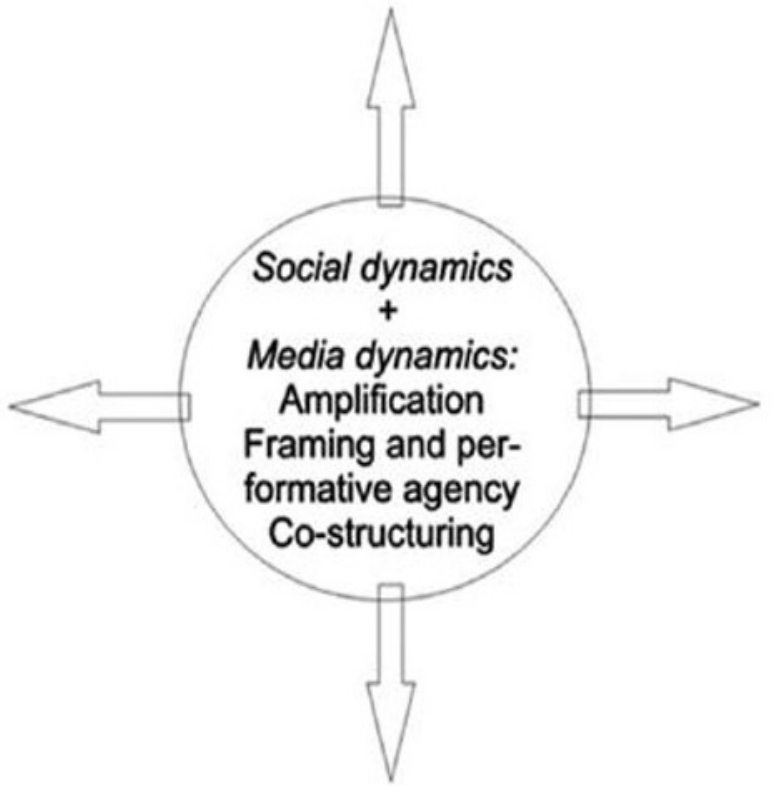

Intensify or prolong conflicts

\section{II.}

\section{Transform \\ existing conflicts}

\section{B}

Figure 1: The dynamics of media construction of religious conflicts illustrated in a model (adapted from AbdelFadil, 2017, p. 462)

\footnotetext{
${ }^{1}$ One of them was the Maitatsine revolt in 1980. Maitatsine's original name was Mohammed Marwa and he was a religious preacher willing to impose his sui-generis religious ideology. 'Maitatsine', in Hausa language means 'the one who damns'. His militants, who were called as 'Yan Tatsine', attacked other religious groups in 1980. And later the Nigerian army was involved in the dispute and throughout the fights approximately 5000 people were killed. Maitatsine also lost his life in the revolt.

${ }^{2}$ Although Figure 1 was designed to study religious conflicts in an online environment (on Facebook to be specific), the model (adapted from Abdel-Fadil (2017) quite relevantly fits the current review discourse on inter-religious conflicts in Nigeria in real life situations. The position of the media at the centre explains its importance in shaping public opinion, moulding public attitude and exiting public behaviour. As Hjarvard et al. (2015) notes the media can reduce or resolve, intensify or prolong, generate new conflicts types or transform existing conflicts through amplification, framing and co-structuring. Hence, the need for media practitioners to be extra careful about the sensitivity of religious issues in Nigeria.

${ }^{3}$ According to Salawu (2009, p. 89) at the wake of the Miss World Beauty Pageant which was scheduled to hold in Nigeria in 2002, ThisDay, a Nigerian newspaper published a story written by one of its Style writers. The story, published in the November 16, 2002 issue of the newspaper was perceived to have been cynical of the Prophet Muhammad (Peace be Upon Him). That story did not go down well with Muslims in the country; hence violent attacks erupted between Muslims and Christians resulting in the burning of places of worships (churches and mosques) killings, maiming and destruction of property.
} 